\title{
The Search of Safe Harbour from Capitalist Imperialism in Seize the Day
}

\author{
Mahmada Khaton Siddika \\ Assistant Professor of English, Centre for University Requirement Courses, \\ International Islamic University Chittagong \\ Email Address: nazu_eng@yahoo.com \\ Umme Hani \\ Lecturer in English, Centre for University Requirement Courses (CENURC), \\ International Islamic University Chittagong \\ Email: uhani0777@yahoo.com
}

Doi:10.5901/mjss.2017.v8n2p195

\section{Abstract}

Seize the Day by Saul Bellow delineates the imperialistic aggression of money creating a society of emotional sterility. Money like an imperialist controls everybody's everything and all are forced to adore money in this novella. Here the father-son relationship is rounded with the financial successful father and the financially insolvent son as in the case of Dr. Adler and Wilhelm. Only his father cares of how much he earns. His marriage life with Margaret is controlled by money and rounded with his paying premiums of policies without giving emotional soothing. So he is always in search of safe harbour to build a deep human connection with every situation devoid of adoration of 'Holy money!' He goes to Hollywood to be an actor for the fulfillment of his wishes, but it remains unsuccessful. He chases his father to be treated as his kid, but his father cares him not as child. Moreover his identity change from Wilhelm Adler to Tommy Wilhelm is to adapt in capital imperialistic society to find a shelter by having free essential self which turns into a failure attempt. He relies on Tamkin for his success in financial war. Tamkin as a means of imperialism has taken the power of attorney over his last seven hundred dollars and captures this little by little placing the mosquito net over his head by visionary ideas and providing all emotional needs which he is eager to have. But his search of safe harbour is continuously torn by the blow of imperialistic tactics of money and is wounded by the moneymaking weapons. This paper aims at how he achieves a safe harbour in funeral of a stranger with 'happy oblivion of tears' by creating a wide vision with his compassion and by the recognition of his connection with common humanity out of capitalist imperialism.

Keywords: Capitalist Imperialism, Wilhelm

\section{Introduction}

Seize the Day by Saul Bellow presents the imperialistic attitude of money in the society of capitalism. Money targets at Wilhelm with his imperialistic weapons- his father, his wife and Tamkin. The aggression of these weapons tears Wilhelm into pieces and makes him impossible to survive in this society. So he always struggles to save himself from the target of these weapons but the more he tries to save him, the more he entangles himself with these. Moreover he always searches a safe harbour to breathe safely and to make a shield for his body from the torture cell of money. Ultimately he finds a safe harbour to make a connection with common humanity and to sustain his compassion for others. The imperialistic clutches of money cannot erase his humanistic nature, but even gives a triumph of him over the escapist animal of capitalistic imperialism.

\section{Methodology}

In testing my hypothesis, I will employ a close study of the above eight fictions covering the area of India, Pakistan and Bangladesh. In other way, I will analyze the secondary sources from critical, autobiographical, historical and related material sources. My hypothesis will be followed by the standard methodology employed in social sciences and my dissertation will be based on textual and comparative analysis of how Wilhelm achieves a safe harbour in funeral of a stranger with 'happy oblivion of tears' by creating a wide vision with his compassion and by the recognition of his connection with common humanity out of capitalist imperialism. I will try my best to take interview of some respective 
writers about their writings, but I will provide no field work, written survey. Above all, the nature of my research will be entitled as a qualitative research.

\section{Capitalist Imperialism}

Capitalist imperialism is a wide concept of applying imperialistic characteristics on contemporary capitalism which denotes the aggression of money in world and the country's relation. Christan Fuchs(2016) says that "imperialism has reemerged and been qualitatively transformed, that through capitalist development and crisis new qualities of capitalism have emerged and others been preserved, and that the new qualities on the one hand constitute a return to capitalist imperialism". For David Harvey (2005), "Capitalist imperialism is a dialectic of political actors that command a territory ( logic of territory) and capital accumulation in space and time (logic of capital)". The basic characteristics of capitalist imperialism - the concentration of capital/ money, the dominance of finance capital and the monopolistic possession of money become apparent. Though the capitalist imperialism is applied in the world and country's relation, I want to apply this in personal relationship in Seize the Day. On the basis of these three points, I want to reread Seize the Day and want to present the life of Wilhelm who is in suffocation of capitalist imperialism and is constantly in search of safe harbor, because everybody's life is controlled by the imperialistic attitude of money and everybody are forced to adore money " they love money ... They adore money! Holy money! Beautiful money! It was getting so that people were feeble-minded about everything except money" (36). Joyshree Deb (2014) in "Materialism Precedes Murder: Saul Bellow's Seize the Day" unearths that "In his novel, New York is to be represented as the whole money- cultured world where everything is determined by money". So Wilhelm is always trying to get rid of this forced adoration of money. I try to analyze the personality of Wilhelm at first and through which I try to expose the characteristics of capitalist imperialism and try to show how he finds a safe harbour from the clutches of money.

\section{Wilhelm}

Wilhelm, protagonist of mid-forties, in his twenty-four hours' events recollects his life up to his present age through the technique of steam of consciousness in Seize the Day. He is inherited from his mother "sensitive feelings, a soft heart, a brooding nature, a tendency to be confused under pressure" (25). He finds his mother "a friend of the family for twentyfive years" (63). But Wilhelm loses his hope of life expectancy by losing her in her fifties. He has a soft and humanitarian heart, so his mother's suggestion to study in medicine makes him worried that he "might make a mistake and hurt someone even kill a patient." (16) and he does not get "that sort of brains" (16). Wilhelm is not infatuated person of acquiring money who is not chasing" five thousand a week" (10) and is not in need of "that sort of money, but only the assistance; not even assistance, but just the feeling" ( 56). His idealistic attitude and simplicity do not fit for this society of complexity and machinery. He wants pity from anybody thinking that " people are ready to give it just because you need it" (93) and tries to live in this capital imperialist society expecting that anybody makes him carry in this society. Wilhelm is a part of those people who are "trying hard, miserable, in trouble, downcast, tired, trying and trying. They need a break... A break-through, a help, luck or sympathy" (22). When he goes to Hollywood in California, he adopts Tommy Wilhelm from Wilhelm Adler to adjust in capital imperialistic society to find a shelter by having free essential self which turns into a failure attempt ,because "Adler being in his mind the title of the species, Tommy the freedom of the person. But Wilky was his inescapable self." (25). He is in fear of the horrified cynicism of successful man like his father, "Cynicism was bread and meat to everyone" (16). Whenever he meets him, he always taunts him not be successful in any field of this society. He is not a category of free man- rich man of a million income and poor man of nobody's thinking, but he is like a fellow who "has to sweat it out until he drops dead" (49). Wilhelm goes to everybody to make him carry in the stony place, but he sees everyone " ride on me with hoofs and claws. Tear me to pieces, stamp on me and break my bones" (105). Kathryn Vanspanckeren (2016) in Outline of American Literature says that "Bellow's Seize the Day (1956) is a brilliant novella centered on a failed businessman, Tommy Wilhelm, who is so consumed by the feelings of inadequacy that he becomes totally inadequate- a failure with women, jobs, machines, and the commodities market, where he loses all his money" (Vanspanckeren).

Christian Fuchs (2016) exposes that the characteristic of imperialism, "the capital concentration, is valid today" ( Fuchs) that means in contemporary capitalistic society, because everything- industry, service and finance - is concentrated on the accumulation of money. This concept is apparent in the relation of Dr. Adler and Wilhelm, father-son relation. Chinsu 
Joy (2013) says that Wilhelm's father "is a man whose thoughts and actions is reduced to money and to law and order, even to hoarding". Money is the ticket of everything in the world to him. Dr. Adler is a man of retired and popular doctor of internal medicine, "one of the best in New York" (12) aged on eighty who is "idolized by everyone" (11) for making a name to everyone being a rich person. He earns a self-created praise by publishing an article on him. He is successful in outside world but not in his family life. He does not remember the date of death of his wife and even "Mother was a help to you", this uttering of Wilhelm is like a scene of opera to his father. His daughter, Catherine, anesthetist is in a Mount Sinai with a position. Wilhelm is the only member of the family who "had no education" (13) and is not successful in acquiring money, so his father does not tolerate him and only his father's money "give him power over" (56). He builds a concrete barrier of money that "his own son, his one and only son, could not speak his mind or ease his heart to him" ( 10) . He has possessed an "entirely different world from his sons"( 10). "He behaved toward his son as he had formerly done toward his patients" (11). He concentrates on the outside world of praising for huge money, he in outside world expresses excess of success of his son having a gap of him and his son. Benevolence or softness of character is unknown to him for his son "benevolent deafness had its usual effect on him"(46). His father thinks of him that he needs " the money too badly" (81) but in his twenty years he has "never had a penny of help from anybody" (37). He wants only sympathy and comfort from his father and expects only 'help' without money, " when I suffer - you aren't even sorry. That's because you have no affection for me, and you don't want any part of me" (54). Several times he goes to his father in his distress condition to "put his hands on me and give me his blessings" (57) and to make him his guide without giving money in the society. He is unwilling even to act as a man of comfort for his son by saying "I'm too old to take on new burdens. I'm just too old to do it" (109). He throws him as a dust "I'll see you dead, Wilky, by Christ" (110) at the time of his final financial catastrophe. But Wilhelm even in his estrangement with his father, he does not think of his father's death, "I love him, My father" (92). "The money makes the difference" (55) between father and son. He assures him that if his father were poor, he would show him actual respect, love and care for his father.

Christian Fuchs says that "under imperialism , finance capital commands almost the whole of the money capital of all the capitalists". The dominance of capital in capitalistic imperialism is evident in the relation of husband-wife, Wilhelm and Margaret. They are separated from each other for the mismatch of Wilhelm's idealistic mind and Margaret's capitalistic mind. Their talking and lifestyle are centered round of money. In their twenty years of their relation, money controls their relation. Margaret always forces Wilhelm to be successful financially, but Wilhelm always wants from her love, comfort and emotional soothing which he eagerly longs for. His wife goes out "with other men. But took his money" (94). He leaves her for "he had to" (50). For this, he wants to get divorce from her to marry Olive whom he loves. But she does not let him do. The divorce will give the chance to marry him again. She does not do "to punish him" (94) for leaving her and he must "pay the price of his freedom" (113). At the moment, he needs emotional soothing from his wife, his wife talks with him about the post dated chaque and rebukes him not to be solvent financially. She always encloses "bills for the boys' educational insurance policies" (29) which his mother-in-law has started this but after his death he has to pay the premiums for two years. He has two sons, but they are detached from him, even they do not know "how much he cared for them" (94). "My kids. I love them. I don't want them to lack anything" (46). He does not abandon his son, but his wife keeps them away from him and she does not allow him to see them. The children grow without their father, but he must "pay and pay" (98) for their upbringing. The massage from Margaret for an urgent call makes him worry of his own sons' condition even in his own financial destruction. He is rejected by his father, but he is alert of his own fatherhood.

III

In Capitalist Imperialism, finance capital always tries to as Fuchs says "seize the largest possible amount of land of all kinds and in a place it can, and by any means - by exploitation, 'by means of trusts' etc and 'occupies a monopoly position"'. Since it is a wide view, this theme is applicable for this society of Seize the Day, because in here "the business man, the heartless, flaunting, boisterous business class who ruled this country with their hard manners and their bold lies and their absurd words that nobody could believe" (63) and the competition- factor manifests "itself in different individuals" (64) in everywhere. The real thing to everyone is the present moment without caring the past and the future. They only consider "the here-and now. Seize the Day." (66). Dr. Tamkin represents this business class and the means of capitalist imperialism.

$\mathrm{He}$ is under the guise of so-called psychologist captures Wilhelm at Hotel Gloriana with his imperialistic tactics. He meets Wilhelm in a card game who offers him to invest money in commodity share at one of the branches of Wall Street. 
He convinces him by "a calm and rational, a psychological approach" (10) to deposit money partially by opening a small account, because Tamkin knows the branch manager. He applies his theory- "act fast-buy it and sell it; sell it and buy in again. But quick!" (8) on him. He emphasizes to get out from it in a same day by making profit. He makes alert him that "people lose because they are greedy and can't get out when it starts to go up" (9). He announces some successful men "who make five, ten thousand a week just fooling around" (9), just to make sure of the success to invest in this commodity share.

Finding no other shelter from his father, "he found himself flowing into another channel" (57), Dr. Tamkin, and this man's sight brings "his quarrel with his father to a close" (57). Wilhelm's need of guide to survive in the society becomes a means of Tankin to capture his last deposited money. He applies all kinds of trust method by showing all documents of his honesty in words "I have to do good where I can ... Without a financial reward. I remove myself from social influence. Especially money. The spiritual compensation is what I look for" (66) and by telling the false story of his profession "been in the underworld" " head of a mental clinic in Toledo" working "with a Polish inventor" "Egyptian royal family as a psychiatrist" (67). Accordingly he brings forth of all other people's negative attitude "to go to the market with murder in their heart" (10). He catches Wilhelm's obsessive look to utilize his imperialistic sense to capture him. Using the means of trust, he makes an affirmation for himself in the life of Wilhelm, "Tamkin was everything that he claimed to be"(57). Thus he spreads the mosquito net over his head that he has no other way without trusting him. He finally signs a chaque of his last saving of seven hundred dollars. But Tamkin though with an equal share on lard and rye gives only three hundred dollars to promise him to give the remaining portion in the next day. He collects the power of attorney from Wilhelm "to speculate with his money" (59). He falls himself on the position "either broke or rich" (60). He does not reconsider that "his interest in the market was theoretical" (61). Tamkin exercises his psychological principle of hypnotic power over him which gives him "with an expression of quiet triumph about his mouth, almost suggestion of a jeer" (61).

At the same time, he makes him "warm and pleasant" (65) forgetting his father and anxieties of his life by the humorous presentation of a story of wife and husband and fears him much by the story of tall handsome girl of epileptic and young cameraman. The realistic presentation of fantasy idea and fabricated story of his own father entangle him not to come out of it. He basically attracts him not to "wish hard enough for money, and therefore I come with a cool head to it" (70). The metaphysical idea- pretender soul and real soul attracts him most because he always wants to get rid of the pretender soul of present capitalist imperialism. Ironically he falls into a means of capitalist imperialism, "the pretender soul takes away the energy of the true soul and makes it feeble, like parasite" (71). Whenever he doubts his vision of "kind, ordinary, helpful people" (72) because they are "out in the country" (72) of capitalistic society, he taunts him not to apply his mind to his vision. Then he turns him to the sweetness of his trap. The shrewdness means of capitalist imperialism sucks Wilhelm's blood to the last drop that even he is unable to "get out with a small loss" (88) in the gamble market. He uses his "here-and-now mental exercise" (89) on Wilhelm and knocks at his weak point of his father and wife continuously.

When he tells of his wife's story and story of Mr. Rappaport, he understands his lying, he has "to go along with him. It's too late. I can't get off" (96) but it leads him to "a day of reckoning" (96) to the ultimate truth. His talking with "spontaneous emotion and open receptors and free impulse (96) and humbleness open a room for him in Wilhelm's heart. In every situation of Wilhelm, ingenious Tamkin entangles him by analyzing every situation with idealist but false philosophy. His statistic revelation of the condition of people who wants to live or not to live in the world moves him profoundly and takes back him on his trigger of imperialism. He victimizes him with his own idealistic notion as he does not refuse to respect the man Mr. Rappaport to take him to the cigar store. Keith Opdahl (1967) says that Saul Bellow presents Wilhelm as "the destruction of man by his humanitarian ideals". He easily turns his concentration from the market. The market/ share of lard is falling "down to .19 and had dropped twenty points since noon" (103) and as it is for rye also. He is out of name in financial society. He madly searches for Tamkin, he does not find him in the market and in the Gloriana Hotel.

\section{IV}

Wilhelm has a limitation that "he had decided that it would be a bad mistake to go to Hollywood, and then he went. He had made up his mind not to marry his wife, but ran off and got married. He had resolved not to invest money with Tamkin, and then had given him a check" (23). For this limitation of his character, he always searches for a safe harbor from the imperialistic clutches and torture of money which will act as his support and his guide in this complex life, because we cannot overlook the fact that it is Jacob John Clayton (1979) in Saul Bellow: In Defense of Man expresses, "the greatness of man and that we are not gods, not beasts, but savages of somewhat damaged but not extinguished nobility. 
At last he finds a safe harbor when he is in the line of carrying coffin of a dead body, "gazing at the face of the dead" (116) though he hears " the beating of his heart anxious, thick and frightening" (116), this sound seems "somehow also rich" (116), because he is able to attach himself with a common humanity which everybody fears to be, "when he looked at the corpse, and his face swelled, his eyes shone hugely with instant tears" $(116,117)$. He utilizing and hearing his heart cries a lot. "A man-anotherhuman creature, was what first went through his thoughts" (117). Chinsu Joy (2013) says that "Bellow's water imagery contains both possibilities that symbolize the rigorous life forces which destroy Wilhelm and a transcendent reality which raises him above destruction". He amidst of the crowd of hunters of capital stands himself " in the center of a crowd by the great and happy oblivion of tears" (118). He only finds a secure place to attach himself with common humanity having humanitarian quality to survive in this concrete society by giving a triumph of humanitarian ideas. This idea will give him future shelter from any battle of capitalist imperialism. Joy also says that "Wilhelm's suffering leads him to the recognition of his kinship with common humanity, for whom he now feels compassion". Since sorrow and joy are consecutive through sorrow, he finds the instinct of happiness by crying "toward the consummation of his heart's ultimate need" (118). Capital is earned in a teenage period using their energy in a full force. Wilhelm's age is not perfect to define himself financially successful in this society, Joy again exposes that "the materialism of society means that the values of the heart are trampled on because everything revolves around money. Wilhelm is unable to establish the deep human connection that he longs for". Hong Wu (2013) in "Seize the Day: An Existentialist Look" says that "It is a belief of optimism in pessimism. After that doom day, Wilhelm will continue making free choices and defining himself by his series of acts. It is hinted that he will move out of New York to live in Roxbury, like Herzog's choice to live in the countryside, and will make up with Olive in the future". "I can't take city life any more, and I miss the country. There's too much push here for me. It works me up too much. I take things too hard. I wonder why you never retired to a quieter place" (44). "I'll get a divorce if it's the last thing I do... As for Dad-As for Dad- I'll have to sell the car for junk and pay the hotel...'lll try to start again with Olive" (115). Joy also says that "the implication of the final scene of the novel, where Wilhelm cries at a funeral of a stranger, is that he has overcome his excessive self-consciousness and has really becomes that ' visionary sort of animal' (39) superior to the materialistic escapists ubiquitous in the contemporary society of Seize the Day".

\section{Conclusion}

In conclusion we can say that since the practicality of his safe harbour is questionable to everyone, his humanistic sense will create a foundation of his safe harbour which assures his survival with common humanity, not as like as the escapist of capitalist society. Though he will not able to build this safe harbour in the city of capitalist imperialism, he will easily build this in calm and soft environment of village where his simplicity finds a soothing place. He with a meaningful sense of life and death, not as a man of existentialist sense of meaningless life, can live with the full consumption of his heart.

\section{References}

Bellow, Saul 1996). Seize the Day. New York: Penguin Publishers.

Christan, Fuch (2016). " Critical Globalization Studies and the New Imperialism". Critical Sociology 36.6: 839-867. Clayton, Jacob John. (1979). Saul Bellow: in Defense of Man. 2nd. London Bloomington: IndianaUniversity Press.

Deb, Joyshree (2014). "Materialism Precedes Murder: Saul Bellow's Seize". IOSR Journal of Humanities And Social Science (IOSRJHSS). 19.1: 59-64.

Harvey, D. A Brief History of Neoliberalism (2005). Oxford University Press: Oxford.

Joy, Chinsu (2013). "The Them of Victimization in Saul Bellow's Seize the Day". Iternational Journal of Creative Research Thoughts 1.11.

Opdahl, Keith Michae (1967). "Come Then, Sorrow". The Novels of Saul Bellow. Pennsylvania: The Pennsylvania State UP: 96-117.

Wu, Hong (2013). "Seize the Day: An Existentialist Look". Journal of Language Teaching and Research 4.2: 437-442.

Vanspanckeren, Kathryn. Outline of American Literature.[Online] Availsable: Outline_us_lit.pdf-Adobe Reader ( July 23, 2016). 
ISSN 2039-2117 (online)

ISSN 2039-9340 (print)
Mediterranean Journal of Social Sciences MCSER Publishing, Rome-Italy
Vol 8 No 2

March 2017 